\title{
The Origin and Impact of Inflation
}

\author{
Remarks by DARRYL R. FRANCIS, President, Federal Reserve Bank of St. Louis \\ Before the Joint Seminar of The Canadian Council of Financial \\ Analysts and The Toronto Council of Financial Analysts \\ Toronto, Canada, November 18, 1975
}

T IS A pleasure to be here in Toronto and to share with you my views on inflation. This is a subject whose poptlarity has fluctuated with cyclical fluctuations in business activity; it is debated during upswings only to recede into oblivion during downswings. Yet, in my opinion, it is a subject which should be analyzed at all times since it is during downswings that the seeds of inflation are sown.

You have suggested that I speak on the monetarist view of inflation. While the framework within which I analyze the causes and consequences of inflation is of the monetarist variety, I think I should mention that what I consider most important does not necessarily represent the views of all monetarists. In order to put things into perspective, I should like to outline this framework of analysis.

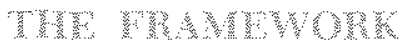

An increase in the total money stock, when it is not accompanied by a similar increase in output, has a predictable effect on behavior. Individuals will attempt to divest themselves of what they consider to be their excess money balances by bidding for other, nonmoney assets. As the prices of these assets rise, output is stimulated. But such increases in output are limited by the growth of resources. Expansion of the money stock produces only a transitory increase in production, while it leads to a permanent rise in the rate of increase of prices. Evidence confirming these results is not difficult to find; rates of growth of money and rates of increase in the price level closely parallel each other when viewed as long-term trends.

A great deal of evidence has been amassed showing that an increase above the trend growth of money which persists for at least two quarters will lead to a rise in the rate of output growth which is quite shortlived. However, as the rate of production returns to its trend level, the rate of inflation increases. We have observed a symmetrical situation for declines in the rate of money growth. Such declines create transitory recessions that are replaced by lower inflation rates in six to eight quarters.

Despite many arguments to the contrary, it is clear that central banks can control the money supply within a very narrow range over a time period of a quarter or more. But if we accept the above relationship between money supply and the price level, why has the money stock been allowed to grow in such a way as to produce persistent and accelerating inflation punctuated by occasional recessions? Have central banks produced this growth pattern through some nefarious design? Have they merely been incompetent? I, for one, believe that neither is the case and that we must look to our political and social aspirations for the root causes of the economic dilemma upon whose horns we sit so very uncomfortably.

In doing this, I shall confine my observations to the American experience, simply because I am most fa miliar with the trials of the U.S. economy. I am quite sure, however, that parallels can be drawn for Canada and many other Western industrialized nations which face the same problems of inflation and unemployment.

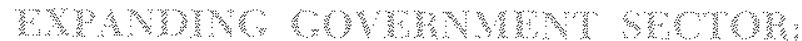

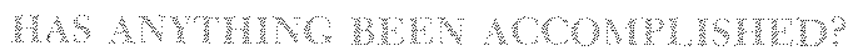

For many years, Government spending and the size of the Government sector have expanded at an increasing rate, Since 1950 total annual Government ex- 
penditures have risen by about $\$ 454$ billion, with $\$ 328$ billion of that having been recorded in the past ten years. This growth was spurred by an underlying philosophy which contends that greater direct Government activity is the best way, if not the only way, to achieve certain economic and social goals. So let us consider the claims of those who espouse this philosophy and examine their validity. Has this spending accomplished what it set out to do? Was it indeed the "best" way? And finally, has it had other consequences, too important to be termed merely "side effects," which have imposed high costs on us all?

\section{Woonomis stribly}

One of the oldest arguments in favor of increased Governmental incursion into economic life holds that fiscal policy is the proper, indeed the necessary, tool to stimulate the economy and combat unemployment. In addition to the automatic stabilizing effects of tax and transfer payment policy, it has been alleged that the Government should introduce significant spending efforts when the activity of the private sector is inadequate for full employment, however defined. And it is argued that this spending should engender deficits, since financing through higher taxes would reduce private purchasing power and frustrate the attempt to expand total demand.

Historically, Government deficit spending has had no stimulative effects except insofar as it was accompanied by monetary expansion. Thus the stimulation desired could have been accomplished directly through monetary expansion without the Government encroachment into the private sector that is inherent in expansive fiscal policy. More important, we know that the fiscal stimulus is only transitory - that the output effects of excessive money growth are quickly dissipated and that the only lasting result is ever ag. gravated inflation. Consider our actual performance. Have we reduced fluctuations in output and employment through the wide use of fiscal deficits and surpluses? Obviously the answer is no. Since the inception of these policies in the early 1930 s, the frequency and magnitude of economic fluctuations have not differed significantly from those prior to that period.

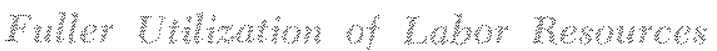

A second popular argument, and on the surface a very persuasive one, states that it is the proper function of Government to employ those resources, particularly labor, which the private sector is unwilling to employ. Presumably, the whole society benefits from such programs at no cost, since additional production is being provided by those who were previously contributing nothing. This is a seductive argument which merits careful examination. Surely we must agree that private enterprise will always take advantage of the opportunity to employ resources which it expects to use profitably. When some resources are not so employed, it means only that their services are not worth the price attached to them.

For the cause of this situation, we must again look to the influence of Government. Hedged in as we have become by laws requiring the payment of minimum wages and "equal pay for equal work," we have seen more and more of the labor force become memployable. And when the Government puts them to work, one basic result is the same. To the extent that these people are being paid more than the market decrees, there is a real transfer of wealth to them from the rest of society. Real output may be greater, but much of the increase in their welfare comes not from their new productivity but from the rest of us.

To gauge the accomplishments of these policies, whatever their redistributive effects, we need only to look at what has occurred. In the face of many jobcreation programs, we find that output growth has risen at approximately a constant trend rate since 1946, irrespective of the rate of Government spending. And in the same period, unemployment fluctuated around an average of 4.9 percent until its recent increase.

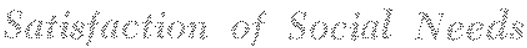

An argument of more recent vintage maintains that the goods and services provided by the private sector in response to society's demands do not respond to the so-called "true needs" of society. It follows from this that the Government should divert resources to the satisfaction of these needs. More and more programs have been enacted in areas ranging from health care to cultural pursuits. Whether they have increased our welfare is highly questionable. We have obtained these services only by sacrificing other things we would have chosen for ourselves. But in their efforts to make it appear that there is indeed such a thing as a free lunch, our elected officials have increased Government expenditures without attempting a corresponding rise in taxes. As a result, monetary growth and inflation have provided the means of transferring control of resources from private hands into the hands of bureaucrats who, it would seem, know our needs better than we ourselves do. 


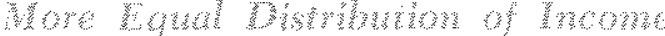

Finally, implicit in all the arguments of the advocates of interference is the assumption that an expanded Government role in economic activity will, and should, redistribute income in the direction of some notion of greater equality. Whether this redistribution is indeed desirable is an argument which has probably existed since the first two humans met. I will not attempt to make any enlightening contributions to that debate. It is fair to ask, however, what has been achieved. In spite of the expanding role of Government activity since World War II, the distribution of incone has changed very little. The income group representing the lowest twenty percent received 5 percent of total income in 1947 and 5.5 percent in 1971 , while the share of the highest 20 percent fell from 43 percent in 1947 to 41.6 percent in 1971. This can hardly be considered a significant accomplishment, expecially in view of the costs incurred.

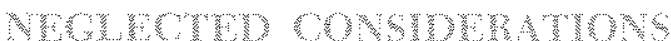

These proposals to improve our socio-economic welfare have, through design or through ignorance, overlooked the problem of financing the additional expenditures. The basie issue in the finaneing of Govermment programs is that resources have to be trans. ferred from one sector of the economy to another. This can be accomplished in only three ways. One is to tax current private consumption and investment - that is, to increase taxes. The second is to tax future private consumption by incurring a deficit and selling Government securities to the private sector. This method moves resources immediately by reducing the purchasing power of security buyers only, but ultimately spreads the burden to all taxpayers when the securities must be redeemed. And the third is to finance the deficit by indirectly selling securities to the central bank which buys them with newly created money.

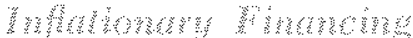

When deficits are financed by the sale of Government securities, the attendant additions to the demand for credit must exert upward pressure on interest rates. Aside from directly discoturaging private consumption and investment spending, higher interest rates, like taxes, are politically undesirable. Hence, these first two methods have typically not been favored. If the central bank must submit to political pressure to contain increases in interest rates, the solution is clear. The monetary authority is compelled to buy at least a portion of the Government issues from the private sector. This action undoubtedly mitigates the initial pressure on interest rates, but at the same time it stimulates money growth and the ensuing inflation leads eventually to higher interest rates.

The process I have outlined here is not hypothetical; we have seen it in operation over the greater part of the past thirty years. Since 1950, the Federal Government's debt has grown by $\$ 176$ billion. In that same period, the Federal Reserve System's holdings of debt have grown by $\$ 68$ billion and the money stock has increased by $\$ 176$ billion. Meanwhile, proponents of deficit spending as a stimulus have proudly pointed to their successes as they saw output and employment increase - however briefly - with each new deficit, and considered the attendant inflation a small price to pay for the short-run achievements.

To sum up; there is no convincing evidence that increased Government spending, with its accompanying deficits, has accomplished its stated social goals. There is no evidence whatsoever that it is the most efficient way to pursue these goals or even that any benefits have exceeded the costs involved. On the other hand, there is overwhelming evidence that it has led to our persistent inflation. I can therefore say unequivocally that not only are the causes of inflation identifiable, but they can be eliminated. That they should be eliminated becomes clear once we consider the consequences of inflation.

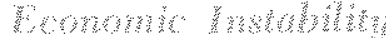

One of these results is that it can inspire monetary policies which reinforce inflationary pressures. I have already discussed the fact that increased Government borrowing exerts an upward pressure on interest rates. When the central bank is then called upon to monetize a part of the debt in order to counteract that pressure, inflation ensues. Each time this process has been pursued, interest rates have not stayed down for long. As people become aware of inflation and the expanded money supply, they expect prices to rise further. Interest rates rise as inflationary premiums are incorporated into them. The central bank again attempts to resist the rise by increasing the money supply and the whole cycle is renewed.

A closely related policy-induced effect is the recessions brought about by recurrent efforts to reduce inflation rapidly and drastically. When the concern for inflation becomes greater than that for interest rates, there are periodic attempts to reduce the rate of price rise by sharp reductions in the rate of money 
growth. These reductions have been responsible for most of our recessions and increases in unemployment.

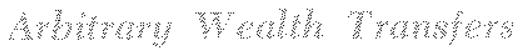

The less visible consequences of inflation are perhaps even more ominous. An inflation which is not fully anticipated brings about a redistribution of wealth from creditors to debtors. When people see this occurring, they will bend their efforts toward protecting themselves from these effects.

Another subtle aspect of inflation is the loss which inflation imposes on all holders of money. Inflation leads all economic units, both individual consumers and firms, to try to maintain smaller money balances and, as they become a more costly productive resource, to make greater attempts to economize on their use. But these attempts require the use of substitute resources, not the least of which are the time and effort involved in devising alternatives to money transactions. I think you can easily visualize where this leads; we are all aware of the inefficiences of bilateral barter transactions. Money is a useful good which permits increased specialization in production and any decrease in that specialization necessarily leads to a reduction in output. The recorded instances of very rapid rates of inflation in Europe and South America convincingly illustrate this fact.

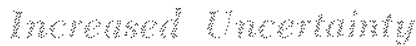

A major consequence of the inflation that we have experienced is the increased uncertainty which has had an impact on every aspect of our economic life. There are really two factors at work here. First, when a society has come to expect a fluctuating inflation rate which cannot be accurately predicted, long-term financial contracts become increasingly risky to both lenders and borrowers; hence, they become increasingly rare. I am sure you are all aware that since the early 1930s the average time to maturity of debt obligations has decreased substantially. Greater uncertainty - that is, greater risk - as to the financing of long-term investment leads to reluctance to undertake stah investment. As a result, productive capacity is lowered and future consumption possibilities are lecreased.

Another source of increased uncertainty, and one whose effects become immediately apparent, is that we have been led to expect the Government periodically to attempt to combat inflation in ways and at times that we cannot predict. Many of these techniques, such as wage and price controls and the re- actions to them, can, and already have, produced serious distortions in the economic process.

An excellent example is the phenomenon observed in the American automobile industry in the past year. Faced with poor sales, manufacturers reacted not with straightforward price cuts, but with elaborate rebate programs which were more costly for both them and their customers. The only reason which I can see for this extraordinary maneuver is that they feared the imminent reimposition of price controls and wished to insure themselves the greatest possible flexibility in the face of this threat.

It is the long-term, often slowly working, and hardly visible effects of inflation, which, in my opinion, represent the greatest danger. They lower the standard of living; they undermine the fiber of our political, economic and social system; and because they are not readily apparent, inflation frequently is considered to be of secondary importance to more visible, but transitory, economic problems.

Our current situation affords us a perfect example of the problems I have outlined. Although it seems that we have reached the bottom of the recession and that recovery is surely underway, unemployment rates remain relatively high and some industries still suffer low rates of growth in demand. As recovery progresses and inventory liquidation ceases it is reasonable to expect that private borrowing will increase; this is bound to exert an upward pressure on interest rates.

Now, how will the Government react to this combination of circumstances? Will it again consciously disregard the dangers of inflation, addressing itself to the short-run unemployment problem with traditionally ill-conceived and ineffective spending programs? Such a course of action will engender massive Government demands on the credit market, adding to the upward push on interest rates. To combat this, money growth must accelerate, bringing with it greater inflation in a year or so and still higher interest rates.

What then? Will aggravated inflation be permitted or will we subject the economy to another recession? Or shall we, alternatively, break from our traditional response, allow the economy to continue the progress it has begun, and not create new problems by attempts to accelerate that progress or to depress the interest rate. These are the alternatives which face policymakers.

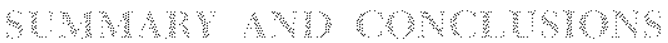

In conclusion, let me restate my fundamental propositions. First, it is quite evident that inflation is the 
result of excessive monetary growth and that demandinduced recessions are caused by sharp downward deviations from this growth path. Second, monetary growth in excess of resource growth has been the most dependable result of Government deficits and the desire to mask the resource transfers that these deficits are assumed to entail. Third, deficits have typically arisen from attempts to change socio-economic conditions - attempts which have, just as typically, been futile.

Solutions are readily available, but they require a time horizon which extends beyond the next election and beyond the short-term outlook and narrow analytical base of many economists. The basic requirement is the realization that all social and economic programs entail a cost which must be paid in one form or another. If this realization becomes prevalent and if the costs become clear, there will be no need for central bank financing of huge Government deficits. Neither will there be a necessity for maintaining interest rates at some predetermined level. In short, there will be no need to fool the electorate. This would free the monetary authorities to control the growth of the money stock, keeping it at a rate consistent with the rate of growth of output and eliminating the major cause of both inflation and demandinduced recession.

Meanwhile, in the current circumstances, it is perfectly feasible to permit interest rates to seek their market-determined level and to start a very gradual deceleration in the trend rate of money growth. It may take a year or two or three, but inflation can be reduced without the emergence of recession. But again, a necessary condition is the discipline imposed by public knowledge that any service provided by the Goverument must be paid for by the public itself and must be paid immediately.

Perhaps such knowledge will reduce demands for Governmental services, or at least eliminate the political pressures to pretend that these services can be provided free of charge. And in my opinion, these pretentions are the major impulses which set in motion the causes of inflation. 